\title{
Detection of Multiple Potato Viruses in the Field Suggests Synergistic Interac- tions among Potato Viruses in Pakistan
}

\author{
Amir Hameed ${ }^{1,2 *}$, Zafar Iqbal ${ }^{1,2}$, Shaheen Asad ${ }^{2}$ and Shahid Mansoor ${ }^{2}$ \\ ${ }^{1}$ Pakistan Institute of Engineering and Applied Sciences (PIEAS), PO Nilore, Islamabad, Pakistan \\ ${ }^{2}$ Agricultural Biotechnology Division, National Institute for Biotechnology and Genetic Engineering (NIBGE), PO Box 577 , \\ Jhang Road, Faisalabad, Pakistan
}

(Received on May 4, 2014; Revised on August 11, 2014; Accepted on August 17, 2014)

\begin{abstract}
Viral diseases have been a major limiting factor threating sustainable potato (Solanum tuberosum L.) production in Pakistan. Surveys were conducted to serologically quantify the incidence of RNA viruses infecting potato; Potato virus X (PVX), Potato virus $Y$ (PVY), Potato virus $S$ (PVS), Potato virus A (PVA), Potato virus $M$ (PVM) and Potato leaf roll virus (PLRV) in two major potato cultivars (Desiree and Cardinal). The results suggest the prevalence of multiple viruses in all surveyed areas with PVY, PVS and PVX dominantly widespread with infection levels of up to $50 \%$ in some regions. Co-infections were detected with the highest incidence (15.5\%) for PVX and PVS. Additionally the data showed a positive correlation between co-infecting viruses with significant increase in absorbance value (virus titre) for at least one of the virus in an infected plant and suggested a synergistic interaction. To test this hypothesis, glasshouse grown potato plants were challenged with multiple viruses and analyzed for systemic infections and symptomology studies. The results obtained conclude that multiple viral infections dramatically increase disease epidemics as compared to single infection and an effective resistance strategy in targeting multiple RNA viruses is required to save potato crop.
\end{abstract}

Keywords : ELISA, Synergism

Potato (Solanum tuberosum L.) is one of the most important vegetable crops in human nutrition having potential of vital food security. It is the fourth largest food crop cultivated in more than 100 countries throughout the world

*Corresponding author.

Phone) +92-412651475-79, FAX) +92-412651472

E-mail) amirhameed73@gmail.com and has gained a status of globally traded commodity ( $\mathrm{He}$ et al., 2012). Potato is infected by at least 40 viruses and 2 viroids (Jeffries et al., 2005) and mixed viral infection is frequent (Kerlan and Moury, 2008). Worldwide the following viruses; Potato virus X (PVX, family; Alphaflexiviridae, genus; Potexvirus), Potato virus Y (PVY, family; Potyviridae, genus; Potyvirus), Potato virus S (PVS, family; Betaflexiviridae, genus; Carlavirus), Potato virus $A$ (PVA, family; Potyviridae, genus; Potyvirus), Potato virus $M$ (PVM, family; Betaflexiviridae, genus; Carlavirus) and Potato leaf roll virus (PLRV, family; Leutoviridae, genus; Polerovirus) are preeminently important, in terms of their distribution, incidence and yield losses (Salazar, 1996). In Pakistan, PVX and PVY have been reported widespread whereas PVA, PVM and PLRV have a much lower incidence (Abbas et al., 2012), but can be of critical importance affecting potatoes in other parts of the world (Nie and Singh, 2000). Within Pakistan, yield shortfalls up to $83 \%$ in potatoes have been accounted due to viral diseases (Mughal and Khalid, 1985). The lack of awareness of viral diseases among potato growers and use of non-certified virus infected seed are the critical factors that may contribute to high prevalence of these viruses in Pakistan.

Mixed infection is often associated with an increase in symptom severity and virus accumulation, in comparison to plants infected by either of the viruses alone, a phenomenon referred to as synergism (Hull, 2002). PVX alone is not that destructive, however it causes severe losses in combination with other viruses such as PVY, PVS and PVA (Barker and Dale, 2006). Mostly PVS, PVA and PVM show very mild foliar symptoms of rugosity, vein deepening and leaf bronzing that are difficult to characterize but co-infection of these viruses influence the severity of symptoms resulting in severe mosaic, mottle, crinkling and rolling of leaves (Dolby and Jones, 1987; Rose, 1983). PVA has been reported causing yield losses up to $40 \%$ in potato by making co-infections with PVX and PVS (Dedic, 
1975). PLRV symptoms are mainly described as primary infection (current season aphid-transmitted) and secondary symptoms (plants grown from infected tubers). The primary infection triggers the rolling of young leaves with upright growth pattern appearing pale yellow, tinged purple, pink or red with many cultivars (cv.). Secondary symptoms turned out to be severe with overall rolled leaves with leathery texture, stunted growth and tuber necrosis (Douglas and Pavek, 1972). Co-infections of PVY and PLRV have caused severe yield losses in terms of reduced tuber size and inferior crop quality than that of single infection of either PVY or PLRV in China (Wang et al., 2011).

RNA silencing is a natural mechanism in plants that counters invading pathogens and regulates endogenous gene expression (Ratcliff et al., 1997). Plant viruses have evolved to overcome this host defense by encoding suppressor proteins that prevent RNA silencing. During mixed infection, these suppressor proteins interrupt host defense based on RNA silencing and result in strong virus-virus interaction that directly facilitate the viruses to accumulate beyond the normal host-mediated limits (Kasschau and Carrington, 1998). The helper-component protease (HCPro) and P3 proteins encoded by potyviruses have been involved in mediating synergism during co-infections (Pruss et al., 1997). Similarly P1 protein of Tobacco etch virus is concerned in enhancing pathogenicity and synergistic interactions between potyviruses and non-potyviruses (Vance et al., 1995).

ELISA (enzyme-linked immunosorbent assay) is the routinely used technique to readily detect most of the potato viruses (Petrunak et al., 1991). On limited resources, it is sufficiently reliable, fast and sensitive approach to test as many as 91 plants simultaneously (Wrobel, 2014). More recently, the multiplex detection platforms including different PCR-based approaches, cDNA macroarray, oligonucleotide-based microarray, tissue print immunoassay (TPIA) and dot blot immunoassay (DBIA) represent an alternative system for large scale viral screening (Maoka et al., 2010; Mortimer et al., 2009; Nicolaisen, 2011; Samsatly et al., 2014).

Previously no studies have been carried out to investigate these synergistic interactions among potato viruses in Pakistan and there is a need to pinpoint the reasons of high epidemiology. The objective of the research work was to look into the effects of these virus interactions through a controlled inoculation experiment and to co-relate the obtained results with field data. The study described here also examined the area-wise prevalence among potato viruses in two major potato cv. (Desiree and Cardinal) in commercial potato zones of Pakistan.

\section{Materials and Methods}

Sample collection. During 2010 and 2011, field surveys were conducted to estimate the incidence of viruses in potato cv. (Desiree and Cardinal). Field selection was based on geographical location, cultivar, crop growth stage and proximity to commercial potato fields resulting in 12 major potato cultivating areas of Punjab province (Fig. 1). A randomized sampling procedure was adopted with a total of 960 (Desiree, 440; Cardinal, 520) leaf samples collected. Each location was divided into 4 plots (field) covering total 80 symptomatic and asymptomatic plants per location and 20 per plot. Excised leaf samples (top, middle and bottom) were individually split in two properly labelled plastic bags; one was used for serological assays and the other was preserved at $-80^{\circ} \mathrm{C}$ for mechanical inoculation experiments. Geographical coordinates of sampling areas were determined using a geographical positioning system (GPS) device (Garmin e Trex $\mathrm{H}$ ) and approximate readings of one sampling site are provided in Fig. 1. Photos were taken from each plant sampled. Samples were stored on dry ice during transportation and then stored in $-80^{\circ} \mathrm{C}$ freezer until use.

Serological detection. Viruses were detected by double antibody sandwich (DAS) enzyme-linked immunosorbent assay (ELISA) on polystyrene microtitre plates (Clark and Adams, 1977). Leaf samples were tested for the presence of PVX, Ordinary strain PVY, PVS, PVA, PVM and PLRV using an ELISA kit according to manufacturer's instructions (Bioreba AG, Switzerland). Purified polyclonal antibodies of respective virus were diluted 1000 times in carbonate buffer ( $\mathrm{pH} 9.6)$ and were coated to each well of microtitre plates $(200 \mu \mathrm{l} /$ well $)$ for $24 \mathrm{~h}$ at $4^{\circ} \mathrm{C}$. Following three washes with PBS-Tween, the plates were coated with diluted leaf sap $(200 \mu \mathrm{l} /$ well $)$ for $24 \mathrm{~h}$ at $4^{\circ} \mathrm{C}$. The plant leaf extracts were diluted $(1 / 10[\mathrm{w} / \mathrm{v}])$ in extraction buffer (0.1\% Tween-20, $2 \%$ polyvinylpyrrolidone (PVP-25), 0.2\% ovalbumin in $0.01 \mathrm{M}$ PBS). After four washes with PBSTween, $200 \mu \mathrm{l}$ of conjugate antibody (Alkaline phosphate conjugated polyclonal virus-specific antibody) was coated in each well for $3 \mathrm{~h}$ at $37^{\circ} \mathrm{C}$. Next after final washing, the plates were incubated with fresh p-nitrophenyl phosphate substrate buffer (adding p-nitrophenyl phosphate tablets $(1[\mathrm{mg} / \mathrm{ml}])$ in substrate buffer) for thirty minutes at $25^{\circ} \mathrm{C}$ preferably in dark. After that absorbance readings were noted using an ELISA plate reader (EL800, Biotech. Instruments, Inc., USA) at $405 \mathrm{~nm}$ optical density, calculating absorbance values for sample wells based on blank test well readings. A plant sample was considered virus- 


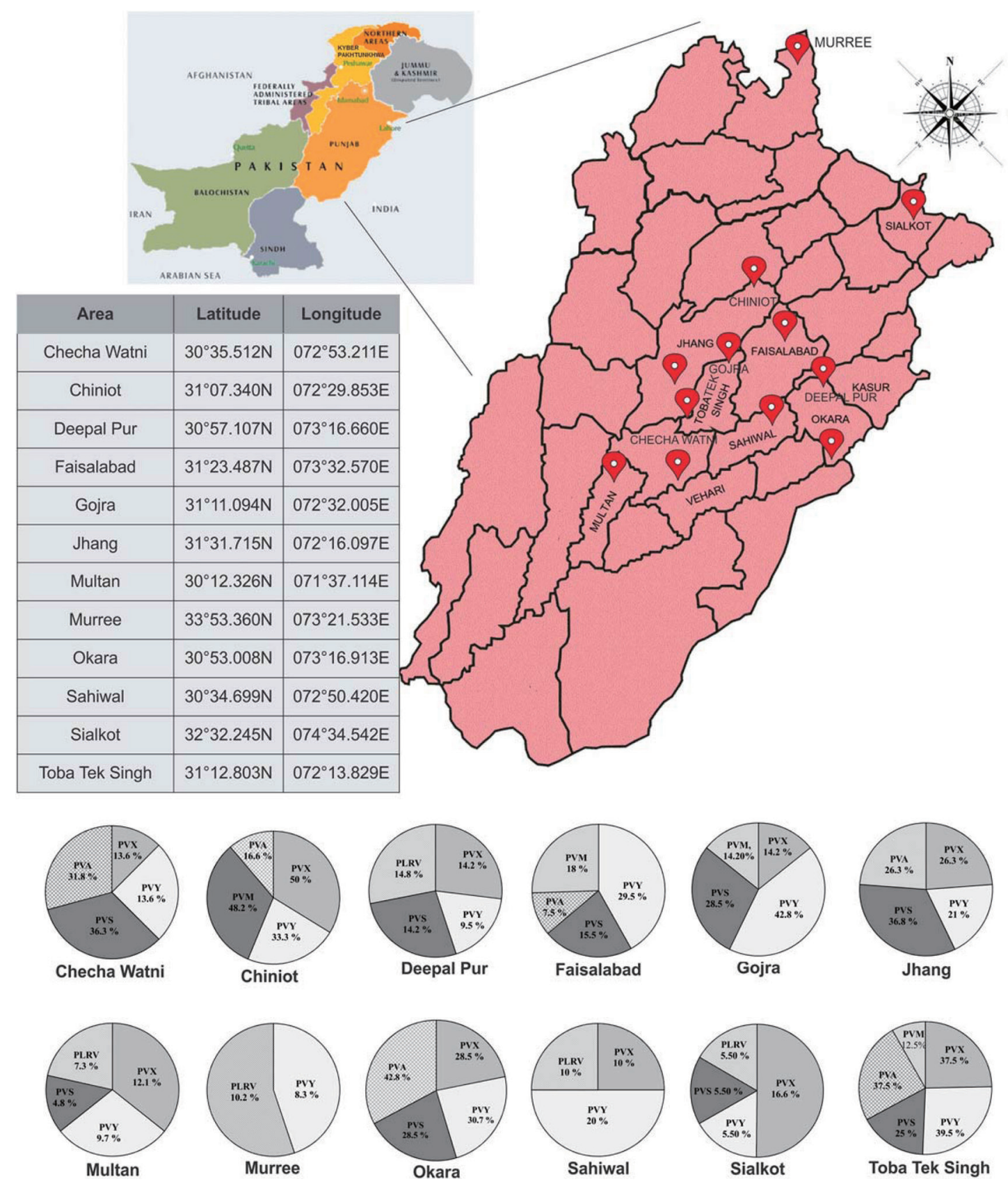

Fig. 1. Viral sampling areas in potato growing regions of northeastern and central Punjab, Pakistan.

Sampling areas

Pie charts show the detected overall viral prevalence $\%$ in two cultivars in each area.

One recorded GPS value from a sampling region is shown

infected having values equal or near to positive controls or greater than three standard deviations of average values of negative controls. To set the cut-off value and calculate the average absorbance value, three replicates of the ELISA were performed.

Glasshouse experiment. ELISA confirmed virus infected samples were selected and further subjected to controlled infection studies. The experiment was laid out according to Randomized Complete Block Design (RCBD). Potato plants cv. Desiree and Cardinal were grown in pots containing a mixture of sterilized sand, field soil, and leaf compost ( $\mathrm{pH}$ 7.2). Leaf sap of the single, double and triple virus infected samples (treatments) was obtained by grinding 
Table 1. Disease incidence percentage of six viruses in potato growing areas

\begin{tabular}{|c|c|c|c|c|c|c|c|c|c|}
\hline Area & Cultivar & $\begin{array}{c}\text { No of } \\
\text { Samples }\end{array}$ & PVX & PVY & PVS & PVA & PVM & PLRV & $\begin{array}{c}\text { Mix } \\
\text { Infection }\end{array}$ \\
\hline \multirow{2}{*}{ Checha Watni } & Desiree & 40 & 8.8 & 15.5 & 22.1 & 11.7 & $*$ & $*$ & 12.1 \\
\hline & Cardinal & 40 & 4.8 & 11.7 & 14.2 & 20.1 & $*$ & $*$ & 6 \\
\hline \multirow{2}{*}{ Chiniot } & Desiree & 40 & 30.5 & 19.5 & $*$ & 8.8 & 13.8 & * & 15.1 \\
\hline & Cardinal & 40 & 19.5 & 13.8 & $*$ & 7.8 & 34.4 & $*$ & 17.2 \\
\hline \multirow{2}{*}{ Deepal Pur } & Desiree & 40 & 14.2 & 5.8 & 10.5 & $*$ & $*$ & $*$ & $*$ \\
\hline & Cardinal & 40 & $*$ & 3.7 & 3.7 & * & $*$ & 14.2 & 4.7 \\
\hline \multirow{2}{*}{ Faisalabad } & Desiree & 40 & $*$ & 20.7 & 15.5 & $*$ & 7.5 & $*$ & $*$ \\
\hline & Cardinal & 40 & $*$ & 8.8 & $*$ & 7.5 & 10.5 & $*$ & 3.25 \\
\hline \multirow{2}{*}{ Gojra } & Desiree & 0 & $*$ & $*$ & $*$ & $*$ & $*$ & $*$ & $*$ \\
\hline & Cardinal & 80 & 14.2 & 42.8 & 28.5 & $*$ & 14.2 & $*$ & 14.2 \\
\hline \multirow{2}{*}{ Jhang } & Desiree & 60 & 26.3 & 15.5 & 26.3 & 17.2 & $*$ & $*$ & 14 \\
\hline & Cardinal & 20 & $*$ & 5.5 & 10.5 & 9.1 & * & $*$ & 7 \\
\hline \multirow{2}{*}{ Multan } & Desiree & 40 & 12.1 & 6 & 4.8 & $*$ & $*$ & $*$ & 4.8 \\
\hline & Cardinal & 40 & $*$ & 3.7 & $*$ & $*$ & $*$ & 7.3 & $*$ \\
\hline \multirow{2}{*}{ Murree } & Desiree & 60 & $*$ & $*$ & * & * & * & $*$ & $*$ \\
\hline & Cardinal & 20 & $*$ & 8.3 & $*$ & $*$ & $*$ & 10.2 & 8.3 \\
\hline \multirow{2}{*}{ Okara } & Desiree & 20 & 18 & 21.9 & 28.5 & 12 & * & $*$ & 13.5 \\
\hline & Cardinal & 60 & 10.5 & 8.8 & $*$ & 30.8 & $*$ & $*$ & 15 \\
\hline \multirow{2}{*}{ Sahiwal } & Desiree & 40 & 10 & 15.5 & * & * & * & 10 & $*$ \\
\hline & Cardinal & 40 & $*$ & 4.5 & $*$ & $*$ & $*$ & $*$ & $*$ \\
\hline \multirow{2}{*}{ Sialkot } & Desiree & 40 & 6.1 & $*$ & $*$ & $*$ & $*$ & $*$ & * \\
\hline & Cardinal & 40 & 10.5 & 5.5 & 5.5 & $*$ & $*$ & 5.5 & $*$ \\
\hline \multirow{2}{*}{ Toba Tek Singh } & Desiree & 20 & 18 & 26.3 & 15.5 & 6.7 & $*$ & $*$ & 8 \\
\hline & Cardinal & 60 & 19.5 & 13.2 & 9.5 & 30.8 & 12.5 & * & 17 \\
\hline
\end{tabular}

*Virus not detected

leaves of each systemically infected plant in $0.5 \% \mathrm{Na}_{2} \mathrm{SO}_{3}$ buffer solution. Leaf saps were filtered through double-layered gauzes and were inoculated to potato plants by softly rubbing the leaves lower side using carborundum powder $(1 \mathrm{mg} / \mathrm{ml})$. Each sap inoculation treatment was replicated three times and one pot grown potato plant was considered as one replication. The inoculated plants were kept in a glasshouse under controlled condition $\left(25 / 21^{\circ} \mathrm{C}\right.$ day/night temperature, $50-70 \%$ relative humidity and $16 \mathrm{~h}$ natural day light photoperiod) and were observed for symptoms development after 1-4 weeks of inoculation.

Statistical analysis. The Generalized Linear Module (GLM) of the Statistical Analysis System (SAS) was used to analyze and interpret the data through statistical package Genstat (VSN International Ltd. UK). Analysis of variance (ANOVA) results were used to calculate least significant differences (LSD) between mean values. For comparing separated means, LSD All-Pairwise Comparisons Test was carried out at a probability level of $\mathrm{P}<0.001$.

\section{Results}

Distribution of potato-infecting viruses across Punjab province. Specific antisera were used in DAS-ELISA to detect the presence of viruses in potato cv. Desiree and Cardinal samples. From the total 960 collected samples tested, results show that the incidence of potato viruses varied greatly across the major potato cultivating areas of Pakistan with different viral infection levels. PVY, PVX, and PVS were the most prevalent, followed by PVA, PLRV and PVM (Table 1; Fig. 1). PVY was detected in all surveyed areas with highest infection levels of (42.8\%) in Gojra (Table 1; Fig. 1). The highest prevalence (50\%) of PVX was detected in samples taken from Chiniot followed by (37.5\%) Toba Tek Singh (Fig. 1). In cv. Desiree, the highest infection levels $(30.5 \%)$ of PVX were observed in Chiniot followed by $26.3 \%$ in Jhang (Table 1) whereas in cv. Cardinal, highest infection levels (19.5\%) of PVX were observed in Chiniot and Toba Tek Singh (Table 1). Interestingly, PVX was not detected in Faisalabad and 
Murree districts (Table 1; Fig. 1). This is possibly due to seed potato tubers in these areas originating from the tissue culture lab of the Virology Section, AYUB Agricultural Research Institute, Faisalabad (http://www.aari.punjab. gov.pk/institutes-sections/plant-pathology-institute/ptpriallied-stations/plant-virology-section-aari-fsd). The third more prevalent virus was PVS with infection levels of $36.8 \%$ in Jhang (Fig. 1). PVS was found with infection levels of $28.5 \%$ in cv. Desiree in Okara and also 28.5\% in cv. Cardinal in Gojra region (Table 1) However, PVS was not detected in Sahiwal, Chiniot and Murree (Fig. 1). PVA and PVM were the least widespread viruses infecting potato crop in sampling areas (Fig. 1). However in Okara, PVA prevalence was found significant with highest infection levels of $42.8 \%$ (Fig. 1). PLRV was found dominant in Deepal Pur and Murree with highest infection levels of $14.2 \%$ and $10.2 \%$, respectively (Fig. 1). PVA, PVM and PLRV were found with highest infection levels of 30.8\%, $34.4 \%$ and $14.2 \%$ respectively, in cv. Cardinal plants (Table 1).

Detection of mixed infection. In the field, co-infection of potato was common with 156 of the 960 potato samples infected with 2 different viruses and 53 plants were found infected with 3 different viruses. Mixed infection was differentially observed in two cultivars. In cv. Desiree, PVX, PVY and PVS were mostly identified making interactions whereas in cV. Cardinal, PVM was frequently detected making interactions with PVY and PVX (Fig. 2). The significant interaction was observed between PVX and PVS in cv. Desiree samples, the percentage of co-infection was
15.69\% (Fig. 2). The percentage of co-infection of PVX and PVY was found equivalent with PVY and PVS co-infection (14.28\%) in cv. Desiree plants (Fig. 2). In cv. Cardinal plants, the highest co-infection $(10.56 \%)$ was found between PVY and PVM followed by PVY and PLRV coinfection (4.8\%; Fig. 2). In case of 3 viruses mix infection, the highest incidence $(6.4 \%)$ was observed between PVX, PVY and PVS followed by PVX, PVY and PVM mix-infection (2.56\%; Fig. 2). The least common mix infection was detected between PVX, PVY and PLRV (1.28\%; Fig. 2).

Effects of mixed infections. The ELISA results of the field samples and controlled inoculated plants demonstrated that the mixed viral infection leads to synergism, being most prominent for co-infections of PVX, PVS and PVA with other viruses (Fig. 3). The results showed that the interaction of PVX with either PVS or PVY leads to greatly enhanced PVX titre (Fig. 3A) and a co-incident increase in symptom severity, consisting of yellowing, vein deepening and leaf crinkling as compared to single infected plants (Fig. 4A, D, E). PVY titre was not significantly altered in mixed infection cases (Fig. 3B). PVS co-infected plants with other viruses, including PVX and PVY, showed a slight increase in PVS levels (Fig. 3C). For co-infections involving PVA, the significant interaction was observed with PVS (Fig. 3D). There was no significant increase in PVA titre for coinfections with PVX and PVY (Fig. 3D). PVM co-infection was also found frequently in infected samples. The important synergistic interaction of PVM was found with PVA and PVY mix infection leading to a significant increase in

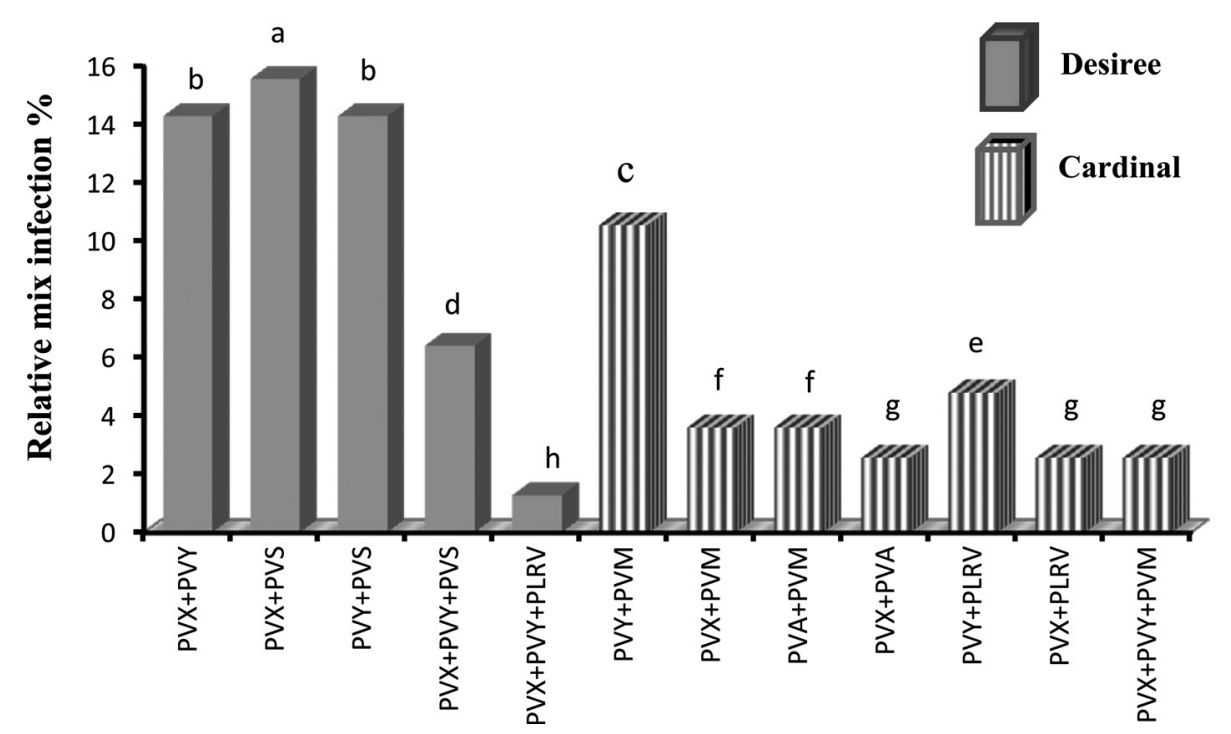

Fig. 2. Mixed virus prevalence in samples collected from all locations. Bars with the same letter ( $b$, $f$ and $g$ ) are not significantly different $(\mathrm{P}<0.001)$ according to LSD All-Pairwise Comparisons Test. The mixed viral infections are compared within each collected leaf sample for general co-infection prevalence. 

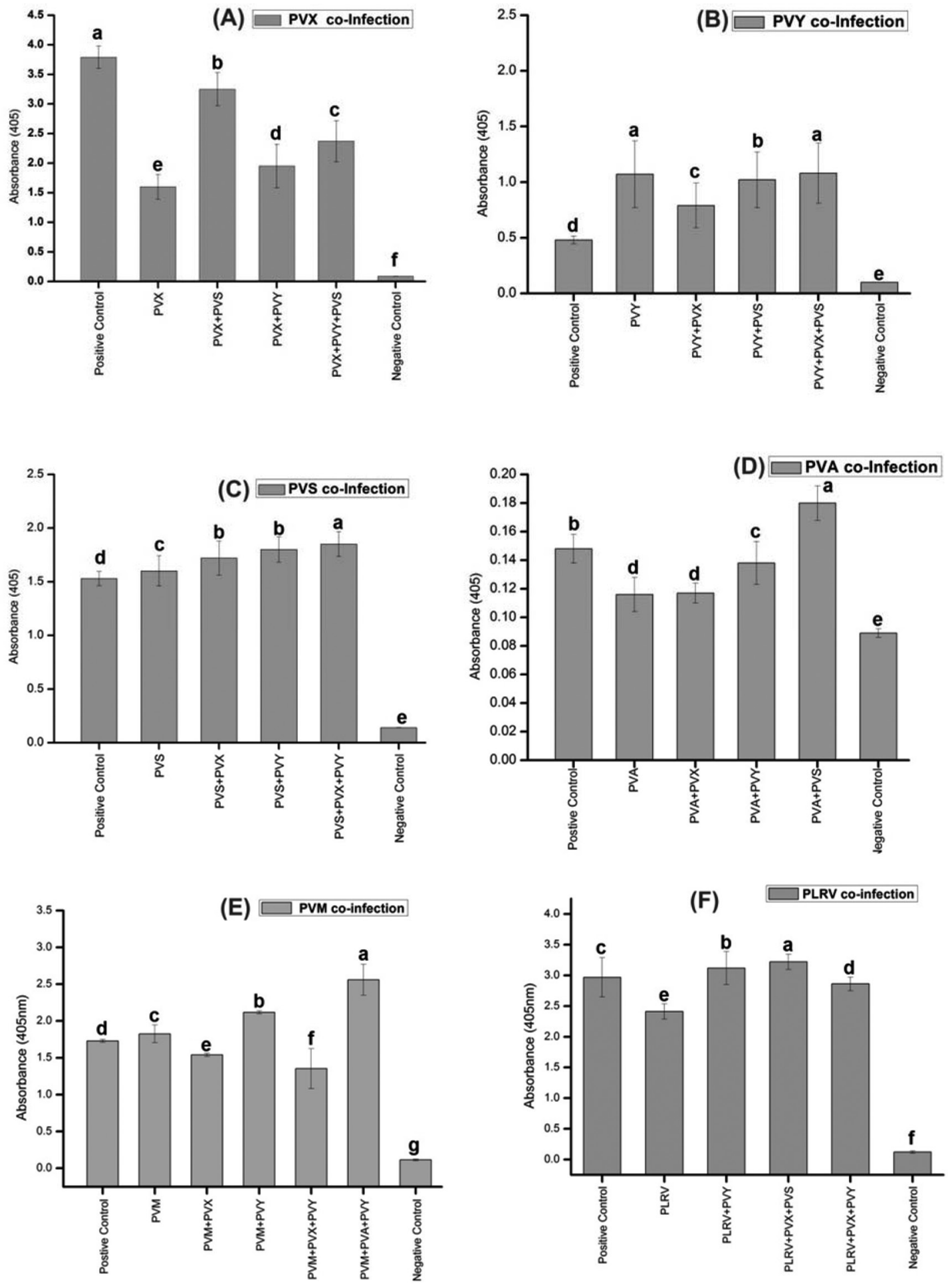

Fig. 3. Absorbance values for singly and co-infected potato plants cv. Desiree. Detection of (A) PVX, (B) PVY, (C) PVS, (D) PVA, (E) PVM and (F) PLRV. The results are grouped according to viruses present in plants. Positive and negative controls were provided with the kit. Bar represents standard deviation of three replicates and represented with the same letter (a, b and d) are not significantly different $(\mathrm{P}<0.001)$.

PVM titre (Fig. 3E). Higher level of PLRV was noted in mix infection, either PLRV present with PVY or with PVX and PVS (Fig. 3F). In most of triple infected plants, the concentrations of all of the three infecting viruses increased 


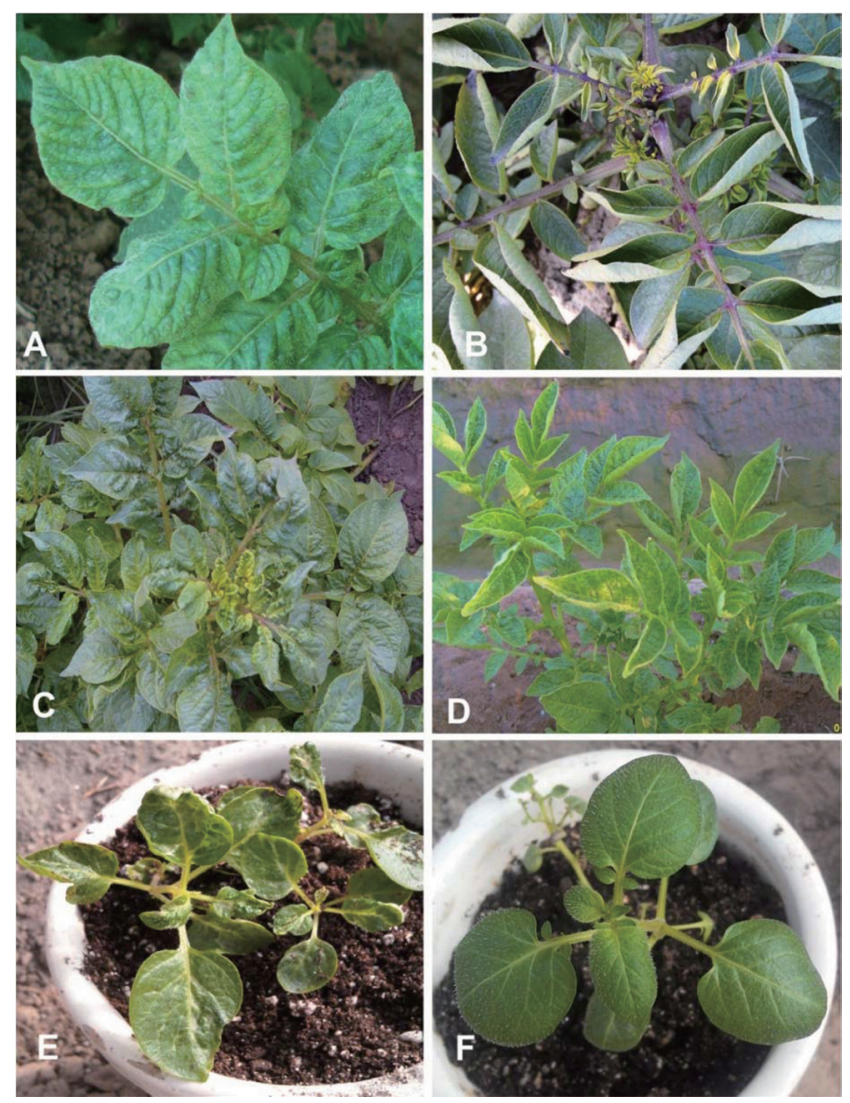

Fig. 4. Potato plants showing viral symptoms in field condition (A) Desiree; PVX infected (mild mosaic and mottling, greening and vein thickening) (B) Cardinal; PLRV infected (severe upward leaf curling, rugosity) (C) Desiree; PVX and PVS mix infection symptoms (severe leaf thickening, yellowing, mosaic and leaf crinkling) (D) Desiree; plant infected with PVX, PVY and PVS (severe leaf thickening, leaf yellowing and severe upward curling, necrotic lesions, sunken veins and mosaic) (E) Desiree; plant symptoms inoculated with PVX and PVS in glasshouse (Leaf thickening, necrotic lesions, mottling and leaf curling) (F) Desiree; Control healthy plants in glasshouse.

as compared to single infected plants (Fig. 3A, C, E, F). For instance, in case of PVX titre, the absorbance reading of triple infection (PVX+PVY+PVS) is higher than that of single PVX infection (Fig. 3A). This data suggest similarity to the phenotypic data from field plants and inoculated plants as infection with multiple viruses showed more pronounced symptoms, consisting of leaf thickening, necrotic lesions, mottling with rough leaves (Fig. 4E).

\section{Discussion}

The results show that the incidence of potato viruses varied greatly across the major potato cultivating areas of Punjab province. PVY, PVS and PVX were the most prevalent, followed by PVA, PLRV and PVM. Earlier studies identifies PLRV as the most prevalent virus in Pakistan (Arif et al., 1995; Ahmad et al., 1995) whereas the recent finding of Abbas et al. (2012) coincides with our current study where PVY and PVX were found major potato infecting viruses in terms of their incidence. This may suggest that the dominance of particular viral strain prevalence has been changed over the last 10 to 15 years.

All potato viruses occur throughout the Punjab province, however PVY, PVS and PVX were more prevalent and this might be due to favorable environmental condition for epidemic development, widespread occurrence, susceptible cv. and the use of non-certified virus infected seed. In current study, the ordinary strain of PVY was detected and there is need for further investigations of different PVY isolates as its epidemiology is directly related to different strains (Hosseini et al., 2011). PVA infection is often symptomless in most of the potato cv. and this might be one reason for the significant detection of PVA in Okara samples because during the field survey it was observed that phenotypically the crop looked very healthy. Due to symptomless crop in current season the local farmers repeatedly use previous year contaminated seed presuming it healthy seed.

PLRV is transmitted in a persistent manner by the aphid Myzus persicae. The prevalence of PLRV is linked to aphid transmission and thus dependent on the timing of sampling (Mirza et al., 1982). Aphid activity starts in March until upto mid of May, whereas here the samples were taken in Dec-Jan. For this reason the results shown here have underestimated the overall incidence of PLRV. In Murree, potato is cultivated in early summer season when the temperature $\left(20-25^{\circ} \mathrm{C}\right)$ is most suitable for aphid activity and this could be one reason that PLRV was found dominant in this area. The high incidence of PLRV in summer crop grown in hilly areas of Murree coincides with some previous research where $1.8-45.5 \%$ incidence of PLRV and PVY was detected in summer crop grown in nearby hilly areas of Murree (Ali et al., 2002).

Different potato cv. responds differently to specific viral specie. Rajabaskar et al. (2013) evaluated response of different potato cV. against PVY and PLRV infection and reported the high susceptibility of cv. Desiree to PVY and PLRV infections. In our results, higher incidence of PVY mix-infections were observed in cv. Desiree plants as compared to cv. Cardinal plants where PVM was mostly detected. The other possible reason for this could be that during survey, most of the cv. Desiree samples were found in small fields where previous year seed was used. In comparison, cv. Cardinal plants were mostly collected from commercial potato grower's fields where they heavily used 
pesticides to control insects responsible for the dispersal of major potato viruses.

Mechanisms of synergistic interactions have been broadly studied in different host-pathogen systems. Several reports show that synergism often involves a member of $\mathrm{Po}$ tyvirus group (Damirdagh and Ross, 1967; Karyeija et al., 2000). The most well characterized synergistic pair is PVX interacting with PVY (Rochow and Ross, 1955). Through quantification of the serological data in infected field samples and controlled inoculated potato plants it was demonstrated that the interactions among different viruses leads to synergism, which ultimately increases the titre of particular virus or both viruses causing severe disease symptoms. The data showed that interaction of non-potyviruses (PVS and PVX) with Potyviruses (PVY) results in greatly enhanced PVX and PVS titre and a co-incident increase in symptom severity. The results presented here are consistent with previous findings where a synergistic interaction between PVX and Potyviruses was observed showing 3 to 10 fold increase in PVX titre, in comparison with singly infected Nicotiana benthamiana plants (Gonzalez-Jara et al., 2004). Similar findings were reported by Vance (1991) where upregulation of PVX accumulation was observed in plants doubly infected with PVX and PVY. Synergistic interactions involving potyviruses have been shown to be a host dependent phenomenon (Wang et al., 2002). Synergistic interactions amongst non-potyviruses were also noted, being most prominent for co-infections of PVS, PVX and PLRV. Our results coincides with Nyalugwe et al. (2012) who reported the interactions between PVX (Potexvirus) and PVS (Carlavirus) with increased PVS titre and enhanced expression of foliar symptoms in co-infected potato plants.

In synergistic interactions, increase in virus titre may regulate other viral traits such as insect transmission and can affect epidemiology (Martin and Elena, 2009). PVS is an aphid transmitted virus that does not induce symptoms in majority of potato cv. while infecting alone. However, PVS has been shown to induce severe symptoms in coinfections with PVX, PVY and PVA (Fraser, 1987). The study presented here has shown a pronounced synergism between PVX and PVS. PVS is a carlavirus and at present, no suppressor has been identified from the virus, although another carlavirus (PVM) is known to encode two suppressors of RNA silencing (Senshu et al., 2011). Many plant viruses encode silencing suppressor proteins (SSPs), which interfere with distinct steps of the host silencing pathways directly or indirectly by countering the small RNA-related processes (Roth, 2004; Voinnet, 2005).

The study presented here shows that six of the common potato viruses are prevalent in major potato cv. in Pakistan but have an uneven distribution. In some areas, particularly Okara and Chiniot, co-infection is common place resulting in synergistic enhancement of disease symptoms. Control of potato infecting RNA viruses is mandatory to reduce yield losses and an effective strategy is required to target multiple viruses simultaneously.

\section{Acknowledgments}

$\mathrm{AH}$ and $\mathrm{ZI}$ were supported by $\mathrm{PhD}$ fellowship from the Higher Education Commission (HEC), Government of Pakistan. The authors thank Mr. Ayub (Pathologist) for the provision of facility to conduct DAS-ELISA test at AARI, Faisalabad and Dr. R.W. Briddon for improving the English in the manuscript. Authors would like to thank reviewer's valuable contribution that improved the manuscript.

\section{References}

Abbas, M. F., Hameed, S., Rauf, A., Nosheen, Q., Ghani, A., Qadir, A. and Zakia, S. 2012. Incidence of six viruses in potato growing areas of Pakistan. Pak. J. Phytopath. 24:44-47.

Ahmad, M., Ahmad, W. and Hussain, A. 1995. Detection of major potato viruses from different potato growing localities of Punjab. In: Pak, PDP/PARC, pp. 175-179. Islamabad, Pakistan.

Ali, A., Hassan, S. and Asad, A. 2002. Incidence of six potato viruses in spring, summer and autumn potato crops of the North West Frontier Province of Pakistan. Aus. Plant. Pathol. 31:143-146.

Arif, M., Mughal, S., Khalid, S. and Hassan, S. 1995. Some biological physical and serological properties of Potato leaf roll virus (PLRV) in Pakistan. Pak. J. Bot. 27:233-242.

Barker, H. and Dale, M. F. B. 2006. Resistance to viruses in potato. In: Natural resistance mechanisms of plants to viruses, Springer, pp. 341-366.

Clark, M. F. and Adams, A. W. 1977. Characteristics of the microplate method of enzyme-linked immunosorbent assay (ELISA) for detection of plant viruses. J. Gen. Virol. 34:475483.

Damirdagh, I. S. and Ross, A. F. 1967. A marked synergistic interaction of potato viruses $\mathrm{X}$ and $\mathrm{Y}$ in inoculated leaves of tobacco. Virology 31:296-307.

Dedic, P. 1975. The effect of Potato virus A (PVA) on yield in some potato varieties. Ochr. Rostl. 11:127-133.

Dolby, C. A. and Jones, R. A. C. 1987. Occurrence of the Andean strain of Potato virus $S$ in imported potato material and its effects on potato cultivars. Plant Pathol. 36:381-388.

Douglas, D. R. and Pavek, J. J. 1972. Net necrosis of potato tubers associated with primary, secondary, and tertiary infection of leafroll. Am. Potato. J. 49:330-333.

Fraser, R. S. S. 1987. Biochemistry of virus-infected plants. pp. 1-7 Research Studies Press, Letchworth, UK. 
Gonzalez-Jara, P., Tenllado, F., Martinez-Garcia, B., Atencio, F. A., Barajas, D., Vargas M., Diaz-Ruiz, J. and Diaz-Ruiz, J. R. 2004. Host-dependent differences during synergistic infection by Potyviruses with Potato virus X. Mol. Plant. Pathol. 5:2935 .

He, Z., Larkin, R. P. and Honeycutt, W. 2012. Sustainable potato production. In: global case studies. 1st ed. Springer, Dordrecht, Heidelberg, New York, London.

Hosseini, A., Massumi, H., Heydarnejad, J., Hosseini, A. P. and Varsani, A. 2011. Characterisation of Potato virus $Y$ isolates from Iran. Virus Genes 42:128-140.

Hull, R. 2002. Matthew's Plant Virology. 4th ed. Academic Press, San Diego, CA, USA.

Jeffries, C., Barker, H. and Khurana, S. M. P. 2005. Potato viruses (and viroids) and their management. In: Potato production, improvement and post-harvest management. The Haworth's Food Products Press, New York, USA.

Karyeija, R. F., Kreuze, J. F., Gibson, R. W., Valkonen, J. P. T. 2000. Synergistic interactions of a Potyvirus and a phloemlimited crinivirus in sweet potato plants. Virology 269:26-36.

Kasschau, K. D. and Carrington, J. C. 1998. A counterdefensive strategy of plant viruses. In: suppression of posttranscriptional gene silencing. Cell 95:461-470.

Kerlan, C. and Moury, B. 2008. Potato virus Y. In: Encyclopaedia of virology, eds. by B. W. J. Mahy and V. Regenmortel, 3rd ed. pp. 287-296.

Maoka, T., Sugiyama, S., Maruta, Y. and Hataya, T. 2010. Application of cDNA macroarray for simultaneous detection of 12 potato viruses. Plant Dis. 94:1248-1254.

Martin, S. and Elena, S. F. 2009. Application of game theory to the interaction between plant viruses during mixed infections. J. Gen. Virol. 90:2815-2820.

Mirza, M. S., Ahmad, M. and Wasim, S. M. I. 1982. Myzus persicae flights and seed potato production in Pakistan. J. Agric. Res. 20:191-200.

Mortimer-Jones, S. M., Jones, M. G. K., Jones, R. A. C., Thomson, G. and Dwyer, G. I. 2009. A single tube, quantitative real-time RT-PCR assay that detects four potato viruses simultaneously. J. Virol. Meth. 161:289-296.

Mughal, S. and Khalid, S. 1985. Virus diseases in relation to potato production in Pakistan. In: 'Potato in Pakistan'. pp. 154165. PARC, Islamabad, Pakistan.

Murphy, J. F. and Bowen, K. L. 2006. Synergistic disease in pepper caused by the mixed infection of Cucumber mosaic virus and Pepper mottle virus. Phytopathology 96:240-247.

Nicolaisen, M. 2011. An oligonucleotide-based microarray for detection of plant RNA viruses. J. Virol. Meth. 173:137-143.

Nie, X. H. and Singh, R. P. 2000. Detection of multiple potato viruses using an oligo (dT) as a common cDNA primer in multiplex RT-PCR. J. Virol. Meth. 86:179-185.

Nyalugwe, E. P., Wilson, C. R., Coutts, B. A. and Jones, R. A. C. 2012. Biological properties of Potato virus $X$ in potato: effects of mixed infection with Potato virus $S$ and resistance phenotypes in cultivars from three continents. Plant Dis. 96:43-54.

Petrunak, D. M., Gildow, F. E. and Christ, B. J. 1991. Incidence and distribution of six viruses infecting potatoes in Pennsylvania. Plant Dis. 75:644.

Pruss, G., Ge, X., Shi, X. M., Carrington, J. C. and Vance, V. B. 1997. Plant viral synergism: the potyviral genome encodes a broad-range pathogenicity enhancer that transactivates replication of heterologous viruses. Plant Cell 9:859-868.

Rajabaskar, D., Ding, H., Wu, Y. and Eigenbrode, S. D. 2013. Different reactions of potato varieties to infection by Potato leafroll virus, and associated responses by its vector, Myzus persicae (Sulzer). J. Chem. Eco. 39:1027-1035.

Ratcliff, F., Harrison, B. D. and Baulcombe, D. C. 1997. A similarity between viral defense and gene silencing in plants. Science 276:1558-1560.

Rochow, W. F. and Ross, A. F. 1955. Virus multiplication in plants doubly infected by potato viruses $\mathrm{X}$ and Y. Virology 1:10-27.

Rose, D. G. 1983. Some properties of an unusual isolate of Potato virus S. Potato Res. 26:49-62.

Roth, B. M., Pruss, G. J. and Vance, V. B. 2004. Plant viral suppressors of RNA silencing. Virus Res. 102:97-108.

Salazar, L. F. 1996. Potato Viruses and their Control. Intern. Potato Center (CIP). Lima, Peru, pp. 214.

Samsatly, J., Jawhari, M., Najjar, C., Sobh, H. and Abou-Jawdah, Y. 2014. Modification of serological techniques and their evaluation for detection of potato viruses in seed certification related activities. Crop Prot. 61:51-57.

Senshu, H., Yamaji, Y., Minato, N., Shiraishi, T., Maejima, K., Hashimoto, M., Miura, C., Neriya, Y. and Namba, S. 2011. A dual strategy for the suppression of host antiviral silencing: two distinct suppressors for viral replication and viral movement encoded by Potato virus M. J. Virol. 85:10269-10278.

Vance, V. B. 1991. Replication of Potato virus X RNA is altered in coinfections with Potato virus Y. Virology. 182:486-494.

Vance, V. B., Berger, P. H., Carrington, J. C., Hunt, A. G. and Ming S. X. 1995. 5' proximal potyviral sequences mediate Potato virus $X /$ potyviral synergistic disease in transgenic tobacco. Virology 206:583-590.

Voinnet, O. 2005. Induction and suppression of RNA silencing: insights from viral infections. Nature. Rev. Gen. 6:206-220.

Wang, Y. Z., Gaba, V., Yang, J., Palukaitis, P. and Gal-On, A. 2002. Characterization of synergy between Cucumber mosaic virus and Potyviruses in cucurbit hosts. Phytopathology 92:51-58.

Wang, B., Ma, Y., Zhang, Z., Wu, Z., Wu, Y., Wang, Q. and Li, M. 2011. Potato viruses in China. Crop Prot. 30:1117-1123.

Wrobel, S. 2014. Modification of ELISA by replacing incubation of microtiter plates in an incubator with their shaking in PVY, PVM and PLRV detection. Am. J. Potato Res. doi: 10.1007/ s12230-013-9355-7. 